University of Nebraska - Lincoln

DigitalCommons@University of Nebraska - Lincoln

USGS Staff -- Published Research

US Geological Survey

2008

Site Fidelity Is an Inconsistent Determinant of Population Structure in the Hooded Merganser (Lophodytes cucull atus): Evidence from Genetic, Mark-Recapture, and Comparative Data

John M. Pearce

1U.S. Geological Survey, Alaska Science Center, 1U.S. Geological Survey, Alaska Science Center, jpearce@usgs.gov

Peter Blums

University of Missouri-Columbia, Puxico, Missouri

Mark S. Lindberg

University of Alaska, Fairbanks, Alaska

Follow this and additional works at: http://digitalcommons.unl.edu/usgsstaffpub

Pearce, John M.; Blums, Peter; and Lindberg, Mark S., "Site Fidelity Is an Inconsistent Determinant of Population Structure in the Hooded Merganser (Lophodytes cucull atus): Evidence from Genetic, Mark-Recapture, and Comparative Data" (2008). USGS Staff -Published Research. 808.

http:// digitalcommons.unl.edu/usgsstaffpub/808

This Article is brought to you for free and open access by the US Geological Survey at DigitalCommons@University of Nebraska - Lincoln. It has been accepted for inclusion in USGS Staff -- Published Research by an authorized administrator of DigitalCommons@University of Nebraska - Lincoln. 


\title{
SITE FIDELITY IS AN INCONSISTENT DETERMINANT OF POPULATION STRUCTURE IN THE HOODED MERGANSER (LOPHODYTES CUCULLATUS): EVIDENCE FROM GENETIC, MARK-RECAPTURE, AND COMPARATIVE DATA
}

\author{
John M. Pearce, ${ }^{1,2,4}$ Peter Blums, ${ }^{3,5}$ and Mark S. LindberG ${ }^{2}$ \\ ${ }^{1}$ U.S. Geological Survey, Alaska Science Center, 4210 University Drive, Anchorage, Alaska 99508, USA; \\ ${ }^{2}$ Institute of Arctic Biology and Department of Biology and Wildlife, University of Alaska, Fairbanks, Alaska 99775, USA; and \\ ${ }^{3}$ Gaylord Memorial Laboratory, The School of Natural Resources, University of Missouri-Columbia, Puxico, Missouri 63960, USA
}

\begin{abstract}
The level of site fidelity in birds is often characterized as "high" on the basis of rates of return or homing from mark-recapture data. For species that exhibit site fidelity, subsequent biological assumptions have included population structure, demographic independence, and that the extirpation of a site-faithful group might be irreversible because of low immigration. Yet several genetic studies have observed patterns of population differentiation that are incongruous with strong site fidelity, which suggests recent isolation, gene flow, or both. Using a 13-year live-recapture and dead-recovery data set, as well as nuclear and mitochondrial DNA collected across the range of the Hooded Merganser (Lophodytes cucullatus), an obligate cavity-nester endemic to North America, we found evidence that gene flow persists across portions of the species' range even though the probability of female breeding-site fidelity is high (0.92; 95\% confidence interval [CI]: 0.64-0.98) and disjunct breeding ranges of this species have been isolated for $\geq 10,000$ years. By combining inferences from genetic, band-recovery, mark-recapture, and comparative data from another cavity-nesting species of waterfowl, we conclude that a high level of site fidelity should not be considered a universal proxy for population structure and demographic independence. Our results also suggest that an accurate assessment of site fidelity-and its implications for population dynamics and delineation-requires cross-species comparisons and multiple data types, such as mark-recapture and genetic information, to best infer patterns across a range of geographic and temporal scales. Received 17 September 2007, accepted 13 February 2008.
\end{abstract}

Key words: band recovery, fidelity, Hooded Merganser, Lophodytes cucullatus, mtDNA, population structure.

\section{La Fidelidad al Sitio es un Determinante Inconsistente de la Estructura Poblacional en Lophodytes cucullatus: Evidencia de Datos Genéticos, de Marcado-Recaptura y de Datos Comparativos}

RESUMEN.-El grado de fidelidad de las aves a un sitio frecuentemente se caracteriza como "alto" con base en las tasas de retorno obtenidas a partir de datos de marcado y recaptura. Las subsecuentes suposiciones biológicas para las especies que presentan alta fidelidad a un sitio incluyen estructura poblacional, independencia demográfica y que la extirpación de un grupo con fidelidad al sitio podría ser irreversible debido a baja inmigración. Sin embargo, varios estudios genéticos han observado patrones de diferenciación genética de las poblaciones, que no son congruentes con una fuerte fidelidad al sitio, lo que sugiere un aislamiento reciente, flujo genético o ambos. Para los análisis utilizamos una base de datos de 13 años de recapture viva y recuperación de individuos muertos, como también de ADN mitocondrial y nuclear recolectados a través del área de distribución de Lophodytes cucullatus, una especie que anida en cavidades de forma obligatoria y que es endémica de Norteamérica. Encontramos evidencia de que existe flujo genético en partes del área de distribución de esta especie, a pesar de que la probabilidad de fidelidad al sitio reproductivo para las hembras es alta (0.92; $95 \%$ intervalo de confianza [IC]: 0.64-0.98) y de que las áreas reproductivas disyuntas de esta especie han estado aisladas por $\geq 10,000$ años. Mediante la combinación de inferencias basadas en datos genéticos, de marcado y recaptura, de recuperación de anillos y datos comparativos provenientes de otra especie acuática que anida en cavidades, concluimos que un alto nivel de fidelidad al sitio no debiera ser considerado como indicador universal de estructura poblacional e independencia demográfica. Nuestros resultados sugieren que una determinación precisa de fidelidad al sitio-y sus implicancias para las dinámicas y los delineamientos poblacionales-requiere comparaciones entre especies y el análisis de múltiples tipos de datos, con información proveniente de análisis genéticos y de datos de marcado y recaptura, para inferir los patrones de la mejor forma posible a diferentes escalas geográficas y temporales.

${ }^{4}$ E-mail: jpearce@usgs.gov

${ }^{5}$ Present address: 1639 Bella Vista Drive, Jackson, Missouri 63755, USA.

The Auk, Vol. 125, Number 3, pages 711-722. ISSN 0004-8038, electronic ISSN 1938-4254. @ 2008 by The American Ornithologists' Union. All rights reserved. Please direct all requests for permission to photocopy or reproduce article content through the University of California Press's Rights and Permissions website, http://www.ucpressjournals. com/reprintInfo.asp. DOI: 10.1525/auk.2008.07154 
STRUCTURED PATTERNS OF genetic differentiation are predicted for species that exhibit natal site fidelity (Avise 2004). Indeed, the historical and theoretical discussions of natal site fidelity (i.e., philopatry) the behavior of limited dispersal from a birth place-focus on how it promotes inbreeding, why inbreeding might be adaptive, and the idea that limited dispersal may lead to differentiation and speciation (Mayr 1963). However, population structure has also been predicted or assumed for groups of adults that exhibit site fidelity to breeding and non-breeding areas, even though natal areas of these individuals are unknown (reviewed in Pearce and Talbot 2006, Pearce 2007). Several population-genetic examinations of avian species presumed to exhibit natal or adult site fidelity (Ransom et al. 2001, Roeder et al. 2001, Kimura et al. 2002, Peters and Omland 2007) or those documented to exhibit high levels of site fidelity through banding studies (Austin et al. 1994, Burg and Croxall 2004, Van Bekkum et al. 2006) found that sampled populations were largely homogeneous at putatively neutral genetic loci. Such "mixed messages" can arise for several reasons, including undetected juvenile dispersal, insufficient time since divergence for site fidelity to contribute to population structure, and the inadvertent inclusion of immigrants in assessments of site fidelity (Pearce 2007). Because vital rates, such as annual survival and productivity, can influence population trends (Sæther and Bakke 2000, Blums et al. 2002), the quantification of breeding-site fidelity and its influence on population dynamics and delineation is of wide interest. Additionally, female-biased site fidelity—common among waterfowl (Anatidae) — has significant implications for population structure, especially with mitochondrial DNA (mtDNA), which is inherited through female lineages (Avise et al. 1992, Peters and Omland 2007).

Several assessments of site fidelity have been made for waterfowl species using either mark-recapture or genetic methods (Avise et al. 1992, Lindberg et al. 1998, Blums et al. 2002, Doherty et al. 2002). With mark-recapture methods, estimates of return or homing rates have been used to infer general levels of site fidelity, though these methods are post-hoc assessments confounded by mortality and permanent emigration (Doherty et al. 2002). More robust measures of return rates can be obtained through estimation of the fidelity parameter $(F)$, which requires multiple live-recaptures of banded individuals on a given study area, as well as the recovery of banded birds outside that study area and throughout the potential range of dispersal and migration (Burnham 1993, Doherty et al. 2002). Similarly, genetic data have been used as indirect measures of site fidelity and dispersal through estimates of genetic distance ( $F$ statistics) and the number of migrants $\left(N_{\mathrm{m}}\right)$ between sampling groups or populations. However, these estimators have been criticized for their unrealistic biological assumptions, such as equal population sizes and symmetrical levels of gene flow (Whitlock and McCauley 1999). More recent estimators include maximum-likelihood and Bayesian methods that have less stringent biological assumptions and infer levels of gene flow and ages of diverged populations (Nielsen and Wakeley 2001). Notably, the "isolation with migration" (IM) coalescent method (Hey and Nielsen 2004) allows assessment of historical versus recent isolation and of migration between groups (see Peters et al. 2005, Omland et al. 2006). Genetic data can also be used to infer demographic processes, such as changes in population size over time (Rogers and Harpending 1992, Emerson et al. 2001).

Here, we apply maximum-likelihood and Bayesian methodologies to live-recapture, band-recovery, and genetic data to evaluate breeding-site fidelity and its effect on population structure in the Hooded Merganser (Lophodytes cucullatus). The Hooded Merganser is a secondary cavity-nesting species, relying on tree cavities that are either excavated by other species or formed through tree growth or decay (Dugger et al.1994). Classified taxonomically as a sea duck (Tribe Mergini), the Hooded Merganser has a disjunct distribution in North America (Fig. 1) and is found in fewer marine habitats than most other members of the sea duck tribe. Patterns of movement and gene flow within and between the disjunct western and central-eastern ranges are not well understood (Dugger et al. 1994), and the historical origins of these ranges are unknown. Fossil records suggest that the Hooded Merganser was likely distributed throughout the central and eastern portion of the present-day United States since the late Pleistocene (Dugger et al. 1994). Natural and anthropogenic habitat alterations are also thought to have contributed to recent increases in population size and spatial distribution across North America (Heusmann et al. 2000, Davis and Capobianco 2006, Pandolfino et al. 2006). Interestingly, these increases have taken place at a time when other species of sea ducks are in decline (table 2 in North American Waterfowl Management Plan, Plan Committee 2004).

\section{Methods}

Band-recovery mapping.-To better understand the spatial extent of annual migratory movements of Hooded Mergansers, we examined band-recovery data from the U.S. Geological Survey Bird Banding Laboratory with permission from all active permit holders. We selected band-recovery data from banding areas that were geographically similar to our genetic sampling effort (Fig. 1A, B). Our final data set included information from three states (Maine, Minnesota, and Missouri) and one Canadian province (Ontario) where birds were marked between April and June, 1962-2006. Recovery data from western North America and Louisiana, where we also obtained DNA samples, were not included because they are few. We examined the distribution of 544 band recoveries comprising 399 hatch-year birds (males, females, and unknown sex) and 145 adult females obtained during regular hunting seasons between September and February, 1962-2007. Because approximately half the hatch-year birds were of unknown sex, we did not examine sex-specific recovery patterns. Direct (birds recovered during the first hunting season after they were banded) and indirect recoveries are also combined, but direct recoveries constituted $\geq 50 \%$ of the total data set for all banding sites (range: $50-67 \%$ ). All recoveries were dead (i.e., obtained through hunters who shot and reported the band number), and no found-dead or live-recapture information was included. Maps of band recoveries were plotted using ARCMAP, version 9.1 (ESRI, Redlands, California).

Breeding-site fidelity.-We used 13 years of live markrecapture and dead-recovery data to estimate the probability of breeding-site fidelity by adult female Hooded Mergansers to compare with levels of gene flow via molecular methods (below). Between 1994 and 2006, we monitored 190 nest boxes placed throughout a $112-\mathrm{km}^{2}$ area in the Mingo National Wildlife Refuge and adjacent Duck Creek Conservation Area (hereafter "Mingo Swamp") located in southeastern Missouri. In each year, we monitored nest boxes for nesting activity from February to June. 

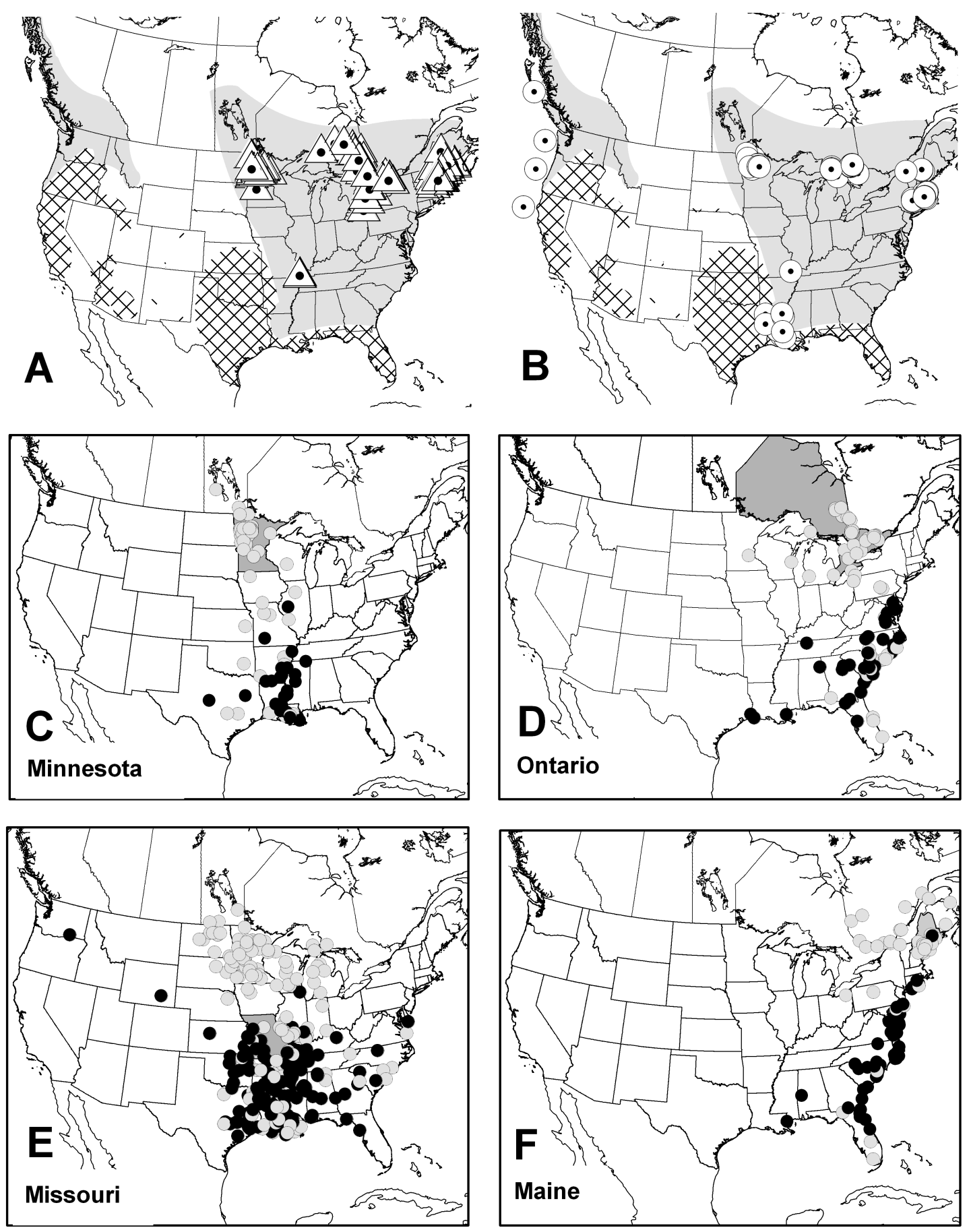

FIG. 1. Maps A and B show the North American wintering (cross-hatch) and year-round (gray) distribution of the Hooded Merganser (modified from Dugger et al. 1994). Breeding birds are now more common in California (Pandolfino et al. 2006), and small wintering areas are also present throughout the central portion of the United States. Triangles in map A depict banding locations used for mapping band recoveries in Minnesota, Ontario, Missouri, and Maine (maps C-F). Circles in map B show distribution of DNA collection locales, and each circle represents $>1$ sample (see Table 2). For samples taken in winter (British Columbia, Washington, Oregon, and California), circles are placed near the state or province of collection. In maps $\mathrm{C}-\mathrm{F}$, the banding state or province is shaded and recovery locations are coded by season: September-November (gray dots) and December-January (black dots). 
At the end of the incubation period, we trapped breeding females and marked day-old ducklings with web tags (1994-1995) or plasticine-filled oval aluminum or stainless steel leg bands (19962006; Blums et al. 1994, 1999). Incubating females captured in boxes were examined for the presence of any marker. Females marked with web tags or aluminum plasticine-filled bands were double-banded with a standard metal leg band. An average of 476 day-old ducklings were marked per year between 1994 and 2006, with 4,891 ducklings marked during this 13-year period. Because the sex of ducklings at the time of banding was not determined, we restricted our analysis to 254 adult nesting females captured in nest boxes, $44 \%$ of which $(n=113)$ were birds known to have hatched on the study area. Thus, we are not estimating natal site fidelity (i.e., philopatry), but breeding-site fidelity of adults, approximately half of which have unknown natal origins.

We formatted capture histories using the live-dead coding in MARK (White and Burnham 1999) and used a grouping variable to assign birds to one of two groups: (1) birds captured in boxes with the presence of a web tag or plasticine band (i.e., natal origin known) or (2) birds captured in boxes with no marks (i.e., natal origin unknown). We used this grouping variable to examine whether birds of unknown natal origin were more likely to have a lower probability of site fidelity than birds known to have hatched on the study area. Sixteen dead recoveries were present in the data set (8 in group 1 and 8 in group 2). We used a Burnham modeling strategy (Burnham 1993, Williams et al. 2002) in MARK, which yields estimates of four parameters: $S_{i}$ (probability of surviving from year $i$ to year $i+1), p_{i}$ (probability of capture given presence), $r_{i}$ (probability of a band being recovered and reported in year $i$ ), and $F_{i}$ (probability of fidelity or returning to the live-recapture study area between year $i$ and year $i+1)$.

We compared competing models with Akaike's information criterion (AIC) adjusted for sample size ( AIC $_{c}$ ) and used $\triangle$ AIC $_{c}$ weights $\left(w_{i}\right)$ to determine the strength of support for a particular model (Burnham and Anderson 2002). We examined goodness-of-fit to our data associated with the most general model by calculating a variance inflation factor $(\hat{c})$. No consistent method exists for assessing fit of this class of models. Therefore, we used a bootstrap approach, acknowledging that this may provide a conservative estimate of $\hat{c}$ (Pollock 2002). This inflation factor was calculated by dividing the deviance of the general model by the mean deviance derived through 500 parametric bootstrap samples created via Monte Carlo simulations in MARK and incorporated as an adjustment to the final model set. Final parameter estimates were obtained via the best approximating model (lowest $\mathrm{AIC}_{\mathrm{c}}$ ).

DNA sample collection and laboratory methods.-To infer levels of gene flow, we collected DNA samples from across the species' breeding and wintering range. Samples of breeding birds came from five areas (Maine and Massachusetts, Minnesota, Missouri, Louisiana, and Ontario) in the central-eastern range (Fig. 1B) and included 123 feathers or egg-shell membranes collected from nest boxes, 14 blood samples from captured birds, and 20 tissue samples. These 20 tissue samples came from the Environment Canada (Wildlife Toxicology Division) Specimen Bank and were collected during breeding months. In the western range, breeding samples were unavailable. Therefore, we used tissue samples from males and females collected during fall and winter months in British Columbia $(n=1)$, Washington $(n=27)$, Oregon $(n=15)$, and California $(n=12)$. These samples included three museum specimens (University of Washington Burke Museum nos. 58203, 58908, and 63732) and 53 tissue samples from hunters that submitted spread wings to the U.S. Fish and Wildlife Service and Canadian Wildlife Service annual Parts Collection Surveys. Extraction of DNA from all these tissue types followed the methods described in Pearce et al. (2004).

For nuclear genotypic data, we screened 66 available waterfowl microsatellite loci for allele variation in a subset of Hooded Merganser samples. From this initial screening, five loci were selected, including Aph $\mu 2$ and Aph $\mu 4$ (Maak et al. 2003), CRG (A. Baker pers.

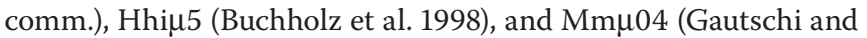
Koller 2005). Polymerase chain reaction (PCR) amplification of microsatellite loci was conducted on a Stratagene 96 Robocycler (La Jolla, California). We also examined several nuclear introns for variation and observed a common polymorphism in the ornithine decarboxylase-7 (OD-7) intron that was characterized by a 19 basepair (bp) insertion-deletion or indel. Because indels can be informative in both phylogenetic and population genetic contexts (Pearce 2006), we developed PCR primers to characterize the presence or absence of the indel in all Hooded Merganser samples. The PCR primers flanking this indel were OD-7 54F 5'-ACTGTTTTGGCAGAACTG F-3' and OD-7 182R 5'-AGTAACAGCCATTTGAGC-3'. The PCR amplification of all nuclear loci during both screening and data collection involved identical reagent cocktails as described in Pearce et al. (2004), except that all were amplified with the same PCR temperature profile $\left(94^{\circ} \mathrm{C}\right.$ for 2 min followed by 40 cycles of $94^{\circ} \mathrm{C}$ for $2 \mathrm{~min}, 50^{\circ} \mathrm{C}$ for $1 \mathrm{~min}$, and $72^{\circ} \mathrm{C}$ for $1 \mathrm{~min}$ ) using an MJ Research PTC-200 thermal cycler. The PCR products were visualized on $6 \%$ polyacrylamide gels using an LI-COR 4200 DNA sequencer (LI-COR Biosciences, Lincoln, Nebraska). Genotypes were scored according to allele size on the basis of an initial comparison to an M13 DNA sequence ladder and then to samples established as size standards that were run on each subsequent gel.

We amplified and sequenced a 437-bp fragment of the control region (domain I) of mtDNA for 134 Hooded Merganser samples using MMCR LH and MMCR LR PCR primers developed for the Goosander (Mergus merganser merganser; Hefti-Gautschi et al. 2008). Samples were amplified by PCR and visualized on $5.5 \%$ polyacrylamide gels using methods identical to those described by Pearce et al. (2004). Because of the common occurrence of nuclear pseudogenes in avian species (Sorenson and Quinn 1998), we verified that amplified sequences were of mtDNA origin by comparing sequences obtained from heart, blood, and muscle samples from the same individual. Sequences were also compared with a homologous mtDNA region for the Hooded Merganser on GenBank (accession no. AY112958; Donne-Goussé et al. 2002) to ensure similarity. Sequences were aligned using ALIGNIR, version 2.0 (LI-COR Biosciences) and collapsed into unique haplotypes with FABOX (Villesen 2007). All haplotypes reported here have been deposited in GenBank (accession no. EF486446-EF486489).

Genetic diversity.-For each microsatellite locus, we calculated allele frequencies, allelic richness (see Kalinowski 2004), and observed $\left(H_{o}\right)$ and expected $\left(H_{e}\right)$ heterozygosity using ARLEQUIN, version 3.0 (Excoffier et al. 2005). ARLEQUIN was also used to conduct exact probability tests for deviations from Hardy-Weinberg equilibrium in each sampling area following the method of Guo and Thompson (1992). We used the program 
GENEPOP (Raymond and Rousset 1995) to test genotypic linkage disequilibrium for each pair of loci in each sampling area. Deviations from Hardy-Weinberg were also assessed by estimating Wright's inbreeding coefficient $\left(F_{\text {IS }}\right)$ across all loci for each sampling area using FSTAT, version 2.9.3 (Goudet 1995). Positive values of $F_{\text {IS }}$ indicate heterozygote deficiency, a signal of inbreeding or population admixture (i.e., Wahlund effect), whereas negative values indicate heterozygote excess. For mtDNA sequence data, we used ARLEQUIN to estimate mtDNA haplotype diversity ( $h$; Nei 1987) and the number of variable or segregating sites $(s)$ within each sampling area as indices of genetic diversity. We graphically displayed the relationship of all mtDNA haplotypes using a network diagram constructed in NETWORK, version 4.2 (Bandelt et al. 1999).

Population differentiation and dynamics.-To examine continental patterns of genetic differentiation within and between western and central-eastern sampling areas, we used an analysis of molecular variance (AMOVA) in ARLEQUIN to generate estimates of interpopulation variance in nuclear allele $\left(F_{\mathrm{ST}}\right)$ and mtDNA haplotype $\left(\Phi_{\mathrm{ST}}\right)$ frequency. For mtDNA sequence data, $F$-statistic analogues were generated using the Tamura and Nei (1993) model of nucleotide evolution as identified by MODELTEST (Posada and Crandall 1998).

We used the isolation with the migration program IM (Nielsen and Wakeley 2001, Hey and Nielsen 2004) to examine whether the disjunct distribution of Hooded Mergansers (Fig. 1) is the result of recent divergence and isolation, gene flow, or both. The IM program uses a Markov-chain Monte Carlo (MCMC) approach to estimate six demographic parameters: effective population size within each of the two disjunct ranges $\left(\theta_{\text {west }}\right.$ and $\left.\theta_{\text {east }}\right)$, the ancestral population size at the time of population divergence $\left(\theta_{\mathrm{A}}\right)$, migration (dispersal that results in gene flow) rates $(m)$ between groups, the time since divergence $(t)$ of the two groups, and the time to most recent common ancestor (TMRCA). We combined samples from all central and eastern locations into a single group to compare with the western group. For initial runs, we assigned wide, flat priors that were assumed to be uninformative for each parameter. We then restricted the range of parameter values around the peaks for final runs. Because estimates of $\theta_{\text {east }}, \theta_{\mathrm{A}}$, and $t$ did not converge well (i.e., tails of posterior distributions did not approach zero), we ran the program multiple times with different maximum priors for these parameters but found no differences in results. The posterior distribution of TMRCA was used to set final priors for the $t$ parameter. We implemented Metropolis coupling using 10 chains with 10 chain-swap attempts per step, a geometric heating scheme (g1 0.9, g2 0.8), and a burn-in period of $10^{6}$ steps, recording results every hour (see Hey and Nielsen 2004). We ran IM three times under identical conditions, but with different random seeds to assess congruence among runs. Because all three runs gave similar results, we report the peak and 95\% CIs of the highest posterior distribution (HPD) of all parameters based on the longest run $\left(31 \times 10^{6}\right.$ steps, $>1,000 \mathrm{~h}$, lowest effective sample size $=288$ ). We estimated the effective number of female migrants per generation $(\mathrm{M})$ between western and central-eastern groups using $M=\theta m / 2$ (Hey and Nielsen 2004), where $\theta$ is the effective population size of the total population $\left(\theta_{\text {west }}+\theta_{\text {east }}\right)$ and $m$ is the migration rate scaled to the neutral mutation rate per generation.

To relate IM estimates to demographic scales, we used a mutation rate $(u)$ of $5.6 \times 10^{-8}$ substitutions site ${ }^{-1}$ year $^{-1}$ (range $4.8 \times 10^{-8}$ to $\left.6.9 \times 10^{-8}\right)$. This estimate is derived from Peters et al. (2005), who estimated a control-region mutation rate of $4.8 \times 10^{-8}$ for domains I and II in the Wood Duck (Aix sponsa). Because our sequence was restricted to domain I, we adjusted our mutation rate using a factor based on the nucleotide diversity of the full fragment of Wood Duck control region (0.0044) compared with the nucleotide diversity of a truncated fragment (0.0052) of identical length to that we obtained for Hooded Mergansers. We then adjusted the mutation rate of Peters et al. (2005) by this factor (1.18) to account for the faster rate of the shorter Hooded Merganser fragment.

Lastly, we calculated mismatch distributions in ARLEQUIN for each sampling area to infer historical population trends and to make direct comparisons with the mismatch distributions of Peters et al. (2005) for the Wood Duck. The mismatch distribution is the observed number of differences between all pairs of haplotypes in the sample (Rogers and Harpending 1992). When the distribution is multimodal, the population is inferred to have maintained a longterm constant size, whereas a unimodal distribution indicates past demographic expansion, with the age of the expansion indicated by the $x$-axis. The mode of the distribution is expressed by the parameter tau $(\tau)$ and can be used to estimate the time to the expansion $(t)$ using the equation $t=\tau / 2 \mu$, where $\mu$ is the product of the number of nucleotides sequenced (437) and the neutral mutation rate for domain I of the control region $\left(5.6 \times 10^{-8}\right.$ substitutions site ${ }^{-1}$ year $^{-1}$; see above). The $90 \%$ CIs of $\tau$ were calculated using a parametric bootstrap approach implemented in ARLEQUIN.

\section{RESULTS}

Band-recovery mapping.-For all banding areas, we observed a general north-south distribution of band recoveries (Fig. 1C-F), though some longitudinal variation is present, especially for the Missouri banding area (Fig. 1E). In northern banding areas (Minnesota, Ontario, and Maine), recoveries occur at progressively more southern latitudes from fall to winter (Fig. 1C, D, F). By contrast, recoveries of both adult and hatch-year birds from the more southern Missouri banding area (Fig. 1E) occur as far north as $49^{\circ} \mathrm{N}$ latitude (southern Manitoba) and along latitudes near the original banding area during the fall (September-November). Northern recoveries of birds banded in Missouri were not observed during winter months (December-February), perhaps because waterfowl hunting seasons in these areas typically end by 1 January. Direct band recoveries of juveniles were also observed to the west of Missouri in Wyoming and Washington (Fig. 1E).

Fidelity estimation.-We captured 254 females or an average of 38 females per year between 1994 and 2006 (range: 20-54 per year). Approximately half (53.7\%) of the capture histories were from a single capture event, with 29 females $(11.3 \%)$ captured $>3$ times. Eight females were captured in $\geq 6$ of the 13 years. Sixteen dead recoveries of adult females were recorded in October and November, 1995-2006, in either the Mississippi migratory flyway (states of Minnesota, Arkansas, Missouri, and Louisiana) or the Central flyway (South Dakota, Oklahoma, and Texas).

Our final candidate set of models used to estimate the probabilities of survival, recapture, reporting, and fidelity parameters included a total of 11 models. We noted little evidence of overdispersion $(\hat{c}=1.11)$ for the most paramaterized model, $S_{(\mathrm{t})} p_{(\mathrm{t})} r_{(\mathrm{t})} F_{(.)}$, which allowed all parameters except fidelity to 
TABLE 1. Models used to estimate probabilities of adult survival (S), capture $(p)$, reporting $(r)$, and site fidelity $(F)$ of Hooded Mergansers banded at Mingo Swamp, Missouri (1994-2006).

\begin{tabular}{lcccc}
\hline Model $^{\mathrm{a}}$ & Deviance $^{\mathrm{b}}$ & Parameters & $\Delta \mathrm{AIC}_{\mathrm{c}}$ & $\boldsymbol{W}_{i}^{\mathrm{c}}$ \\
\hline 1. $S_{(\mathrm{l})} p_{(.)} r_{(.)} F_{(.)}$ & 444.84 & 4 & 0.00 & 0.31 \\
2. $S_{(\mathrm{g})} p_{(.)} r_{(.)} F_{(.)}$ & 443.78 & 5 & 0.98 & 0.19 \\
3. $S_{(.)} p_{(.)} r_{(.)} F_{(\mathrm{g})}$ & 444.26 & 5 & 1.45 & 0.15 \\
4. $S_{(.)} p_{(.)} r_{(\mathrm{g})} F_{(.)}$ & 444.72 & 5 & 1.91 & 0.11 \\
5. $S_{(\mathrm{g})} p_{(.)} r_{(.)} F_{(\mathrm{g})}$ & 443.64 & 6 & 2.89 & 0.07 \\
6. $S_{(\mathrm{g})} p_{(.)} r_{(\mathrm{g})} F_{(.)}$ & 443.71 & 6 & 2.95 & 0.07 \\
7. $S_{(.)} p_{(\mathrm{g})} r_{(\mathrm{g})} F_{(.)}$ & 444.63 & 6 & 3.87 & 0.04 \\
8. $S_{(\mathrm{g})} p_{(\mathrm{g})} r_{(\mathrm{g})} F_{(.)}$ & 443.71 & 7 & 5.01 & 0.02 \\
9. $S_{(\mathrm{g})} p_{(\mathrm{g})} r_{(\mathrm{g})} F_{(\mathrm{g})}$ & 443.61 & 8 & 6.98 & 0.00 \\
10. $S_{(\mathrm{t})} p_{(.)} r_{(.)} F_{(.)}$ & 435.63 & 16 & 15.83 & 0.00 \\
11. $S_{(\mathrm{t})} p_{(\mathrm{t})} r_{(\mathrm{t})} F_{(.)}$ & 416.38 & 39 & 48.25 & 0.00 \\
\hline
\end{tabular}

a Model parameters were constant (.) and varied by year (t) or by group (g), where group 1 were adults known to have hatched on the study area and group 2 were of unknown natal origins. $\mathrm{AIC}_{\mathrm{c}}$ for model 1 was 1,090.01.

${ }^{\mathrm{b}}$ The difference between $-2 \log$ (likelihood) of the current model and $-2 \log$ (likelihood) of the saturated model.

${ }^{c}$ Model weights or probability that model $i$ is the best fit for the data.

vary by time (Table 1); therefore, we did not adjust for lack-of-fit. The best approximating model, $S_{(.)} p_{(.)} r_{(.)} F_{(.)}$, held all parameters constant (no time or group variation). Probability estimates and 95\% CIs from this model were as follows: adult female survival (0.72, 0.61-0.82), capture $(0.62,0.55-0.68)$, reporting $(0.08$, $0.04-0.12)$, and fidelity $(0.92,0.64-0.98)$. We noted some modelselection uncertainty among models $2-4$, though all these models received approximately half the support of model 1 on the basis of $\mathrm{AIC}_{\mathrm{c}}$ weights (Table 1). Model 2 held all parameters constant except survival, which varied by group. With this model, the difference in survival between group 1 (natal area known) and group 2 (natal area unknown) was small (0.70 \pm 0.05 and $0.75 \pm 0.05$, respectively). Model 3 held all parameters constant except for fidelity, which varied by group. Under this model, fidelity was slightly lower for group $1(0.89 \pm 0.07)$ than for group 2 $(0.94 \pm 0.07)$.
Genetic diversity.-A total of 213 Hooded Merganser samples were genotyped for six nuclear loci. Average allelic variation ranged between 2.7 (OD-7) and 11.3 (Aph $\mu 4)$ alleles, but standardized allelic richness was similar across areas (Table 2). Significant deviations from Hardy-Weinberg $(\mathrm{HW})$ proportions $(P<0.05)$ were detected in 7 of the 30 area-by-locus combinations. No consistent pattern of deviation was noted across all sampling areas, except for the Mmu04 locus, which exhibited significant heterozygote deficiencies $(P<0.02)$ in three areas (western North America, Maine and Massachusetts, and Minnesota). Exact tests of genotypic equilibrium showed significant values $(P<0.05)$ in 15 of 90 comparisons, but pairs of loci tested were not consistent across sampling areas (data not shown). Six of the 15 significant linkagedisequilibrium tests were observed within the western sampling area, and this was the only area to exhibit a significantly large $F_{\text {IS }}$ value $(0.147, P=0.002$; Table 2$)$, indicating heterozygote deficiency. This result, along with the number of positive tests for linkage disequilibrium in the western group, suggests some heterogeneity among winter samples (i.e., population structure).

A total of 134 Hooded Mergansers from the six sampling areas were sequenced for $437 \mathrm{bp}$ of mtDNA control region (Table 2). Sequences were identical across different tissue types within the same individual Hooded Merganser, which is similar to a previous mtDNA control-region sequence for this species derived by Donne-Gousse et al. (2002), and were derived primarily from muscle tissue and nest feathers rather than blood. Thus, it is unlikely that DNA fragments amplified in the present study represent nuclear pseudogenes. Forty-four unique mtDNA haplotypes defined by 41 variable sites (all transitions) were identified among the 134 Hooded Mergansers. No gaps or indels were observed. A haplotype network involved numerous hubs and single branches, with no clear phylogeographic clustering of haplotypes either between the disjunct western and centraleastern breeding ranges or among breeding samples within the central-eastern region (Fig. 2). Most mtDNA haplotypes (33 of 44 , or $75 \%$ ) were unique to particular sampling areas, and few were shared among areas.

Population differentiation and dynamics.-Overall estimates of $F$ statistics (genetic distance among all areas) were low and

TABLE 2. Summary statistics for Hooded Merganser mtDNA sequence and six nuclear loci, by sampling areas, including number of individuals, $N$ (and number of mtDNA haplotypes per site), allelic richness $(A)$ averaged across loci, haplotype diversity $(h)$, number of segregating sites $(s)$, and average expected $\left(H_{\mathrm{E}}\right)$ and observed $\left(H_{\mathrm{O}}\right)$ heterozygosities across all nuclear loci.

\begin{tabular}{|c|c|c|c|c|c|c|}
\hline & \multicolumn{6}{|c|}{ Sampling area } \\
\hline & $\begin{array}{l}\text { Western North } \\
\text { America }^{\mathrm{a}}\end{array}$ & Minnesota & Missouri & Louisiana & Ontario & $\begin{array}{c}\text { Massachusetts } \\
\text { and Maine }\end{array}$ \\
\hline \multicolumn{7}{|l|}{ MtDNA } \\
\hline$N$ & $49(17)$ & $9(9)$ & $23(12)$ & $20(7)$ & $14(10)$ & $19(11)$ \\
\hline$h(\mathrm{~s})$ & $0.906(20)$ & 1.00 & $0.920(20)$ & $0.761(11)$ & $0.923(15)$ & $0.900(22)$ \\
\hline \multicolumn{7}{|c|}{ Nuclear loci } \\
\hline$N(\mathrm{~A})$ & $56(4.8)$ & $27(5.0)$ & $35(4.5)$ & $37(4.7)$ & $20(4.3)$ & $38(4.7)$ \\
\hline$H_{\mathrm{E}} / H_{\mathrm{O}}$ & $0.653 / 0.558$ & $0.649 / 0.575$ & $0.641 / 0.593$ & $0.664 / 0.612$ & $0.620 / 0.577$ & $0.651 / 0.590$ \\
\hline$F_{\mathrm{IS}} \mathrm{b}$ & $0.147^{* *}$ & 0.116 & 0.075 & 0.079 & 0.070 & 0.094 \\
\hline
\end{tabular}

$* P<0.05, * * P<0.01$.

ancludes samples from British Columbia, Washington, Oregon, and California.

bositive values of $F_{\mathrm{IS}}$ indicate heterozygote deficiency. 


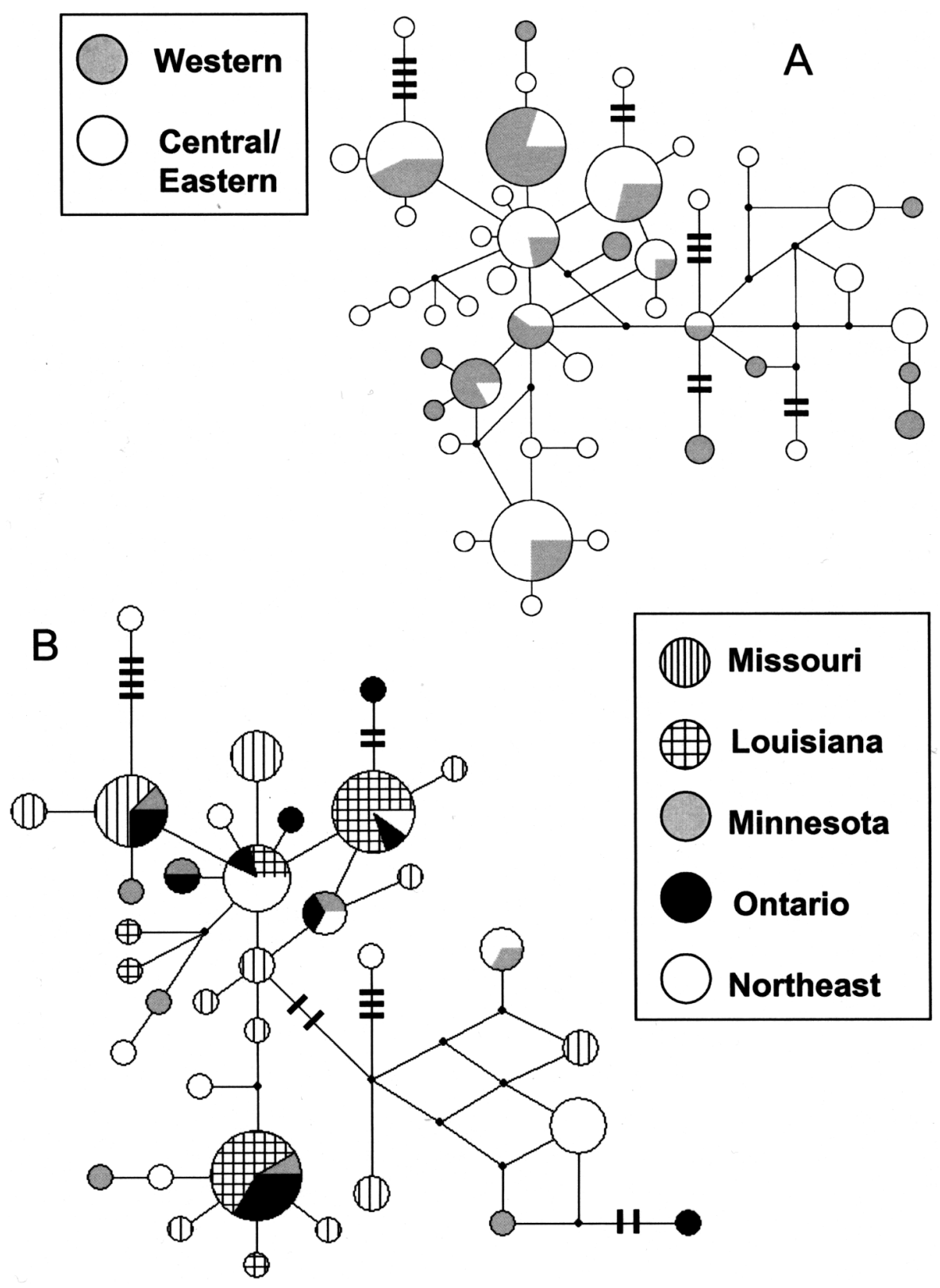

FIG. 2. MtDNA haplotype networks for (A) 134 Hooded Merganser samples (44 haplotypes) observed within western and central-eastern sampling groups and (B) 85 samples (35 haplotypes) observed among breeding samples within the central-eastern group. A single site substitution links each circle except where bars are present, which denote multiple substitutions between haplotypes. Circles are drawn proportionally to observed number of each haplotype. Small black dots are inferred haplotypes.

nonsignificant for nuclear loci $\left(F_{\mathrm{ST}}=0.001, P=0.371\right)$ but higher and statistically significant for $\operatorname{mtDNA}\left(\Phi_{\mathrm{ST}}=0.055, P<0.001\right)$. All but one pairwise value of $F_{\mathrm{ST}}$ for nuclear data were $<0.010$ (Table 3), which suggests greater levels of male-mediated gene flow, as is typical among waterfowl species (Anderson et al. 1992). For mtDNA, significant differences were noted among 6 of 15 comparisons (Table 3), though these did not appear to fit a model of isolation-by-distance. For example, nine haplotypes are shared between the western and central-eastern ranges, but no haplotypes are shared between Missouri and Louisiana (Fig. 2). When we restricted the AMOVA analysis of mtDNA to breeding data (western samples excluded), $\Phi_{\mathrm{ST}}$ remained essentially unchanged $(0.059$, $P<0.001)$, which suggests that greater levels of population structure occur among central-eastern areas as compared with differences between the disjunct ranges.

Parameter estimates from the IM program formed unimodal posterior distributions (Fig. 3), though the tails of distributions for $\theta_{\text {east }}$ (effective size of central-eastern North America), 
TABLE 3. Pairwise table of $F$ statistics across sampling areas for Hooded Mergansers based on mtDNA sequence data (above diagonal) and nuclear genotypic data (below diagonal) ${ }^{\text {a }}$. Overall estimates of $F$ statistics for nuclear and mtDNA data were 0.001 and 0.055 , respectively.

\begin{tabular}{|c|c|c|c|c|c|c|}
\hline & $\begin{array}{l}\text { Western North } \\
\text { America }^{\mathrm{b}}\end{array}$ & Minnesota & Missouri & Louisiana & Ontario & $\begin{array}{l}\text { Massachusetts } \\
\text { and Maine }\end{array}$ \\
\hline Western North America & & 0.022 & 0.001 & $0.114^{* *}$ & 0.043 & $0.071^{* *}$ \\
\hline Minnesota & 0.004 & & 0.023 & 0.044 & 0.035 & 0.004 \\
\hline Missouri & 0.002 & 0.002 & & $0.102^{* *}$ & 0.016 & $0.048^{*}$ \\
\hline Louisiana & 0.001 & 0.005 & 0.003 & & 0.016 & $0.174^{* *}$ \\
\hline Ontario & 0.001 & 0.010 & 0.000 & 0.006 & & $0.090^{*}$ \\
\hline Massachusetts and Maine & 0.000 & 0.006 & $0.012^{*}$ & 0.005 & 0.006 & \\
\hline
\end{tabular}

$* P<0.05, * * P<0.01$

${ }^{a} F$ statistics of mtDNA data based on a Tamura and Nei (1993) model of nucleotide evolution.

${ }^{\mathrm{b}}$ Includes samples from British Columbia, Washington, Oregon, and California.
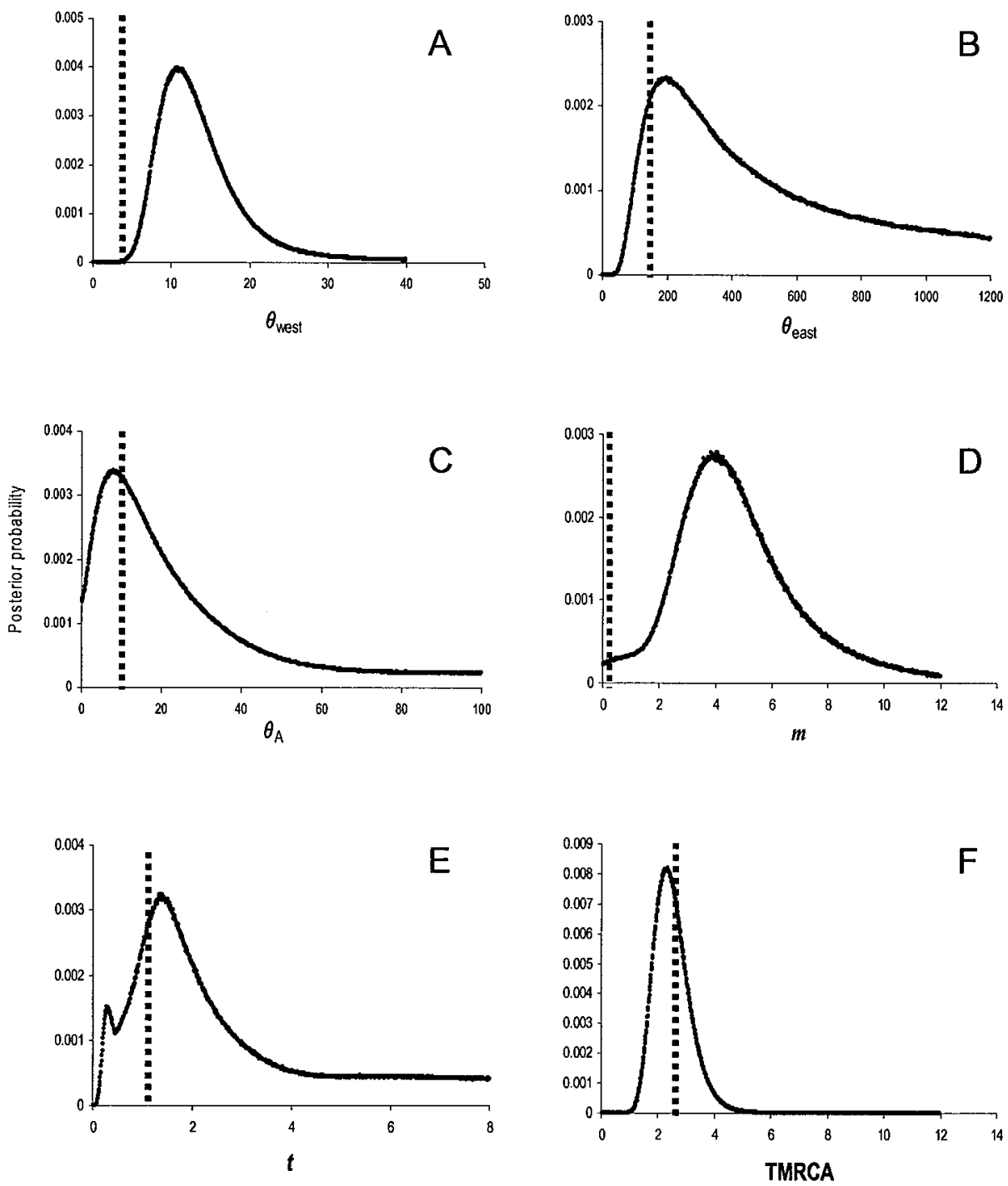

FIG. 3. Posterior likelihood distributions from the IM program showing parameter estimates (peak of each distribution) for (A) $\theta_{\text {west }}$ (effective size of western North America), (B) $\theta_{\text {east }}$ (effective size of central-eastern North America), (C) $\theta_{\mathrm{A}}$ (effective size of the ancestral population), (D) $m$ (migration rate), (E) $t$ (time since divergence of the western and central-eastern samples, and (F) time to most recent common ancestor (TMRCA) for all sampled haplotypes. For comparison, the dashed vertical lines show the peak estimates for Wood Ducks for each IM parameter as estimated by Peters et al. (2005). Note that the peak of the distribution for $m$ in Wood Ducks (D) is at a much lower value than for Hooded Mergansers, but divergence times are nearly identical. 

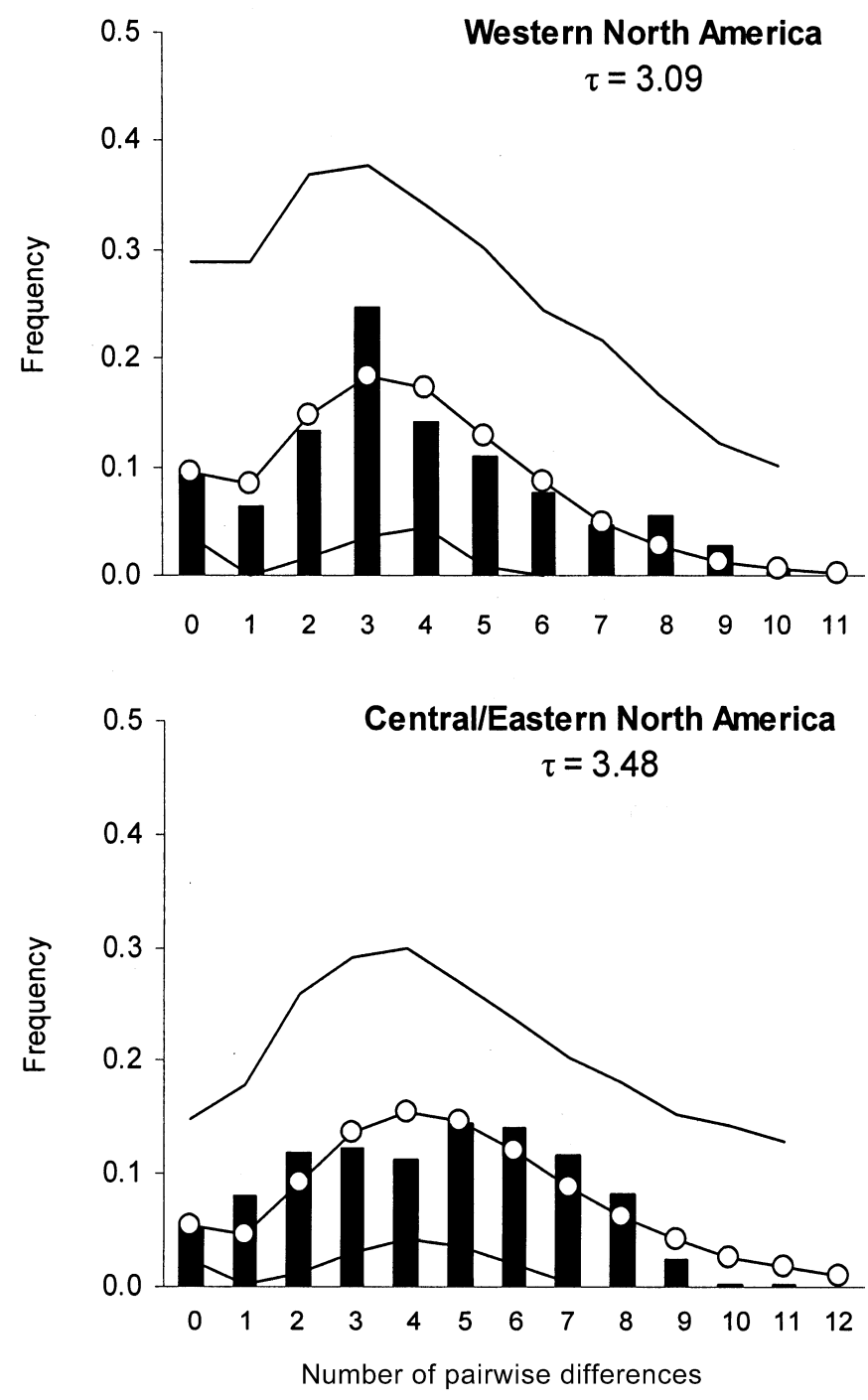

Fig. 4. Mismatch distributions of mtDNA sequence data and estimates of expansion $(\tau)$ parameter for western and central-eastern samples of Hooded Mergansers. Black bars represent observed pairwise distributions between haplotypes, and solid lines with circles represent a model of spatial range expansion. Solid lines show $90 \%$ confidence intervals for the range-expansion model.

$\theta_{\mathrm{A}}$ (effective size of the ancestral population), and $t$ (time since divergence of the two populations) did not approach zero (Fig. $3 \mathrm{~B}, \mathrm{C})$. The posterior distribution for $t$ exhibited a smaller peak to the left of the main peak (Fig. 3E). Setting wider priors did not change the locations of peaks in the posterior distributions (not shown). We observed the estimate of $\theta_{\text {east }}$ to peak at 198.6 (lower 95\% HPD: 103.8), and this was $20 \times$ the size of the estimate for $\theta_{\text {west }}$, which peaked at 10.6 (95\% HPD: 6.5-29.0). The posterior distribution of $\theta_{\mathrm{A}}$ peaked at 7.9 (95\% HPD: 1.6-88.9). The peak estimate for the dispersal rate $(m)$ between western and central-eastern groups was large $(m=4.0)$, and the $95 \%$ HPD did not overlap zero (1.0-9.9), which suggests that we could reject the hypothesis of no gene flow (Fig. 3D). Converting these values of $m$, we estimated the effective number of female migrants per generation (summed over both western and central-eastern groups) to be $\sim 400$ (95\% HPD: 104.6-1,035.0) between the disjunct ranges. The parameter distribution for $t$ peaked at $1.4(95 \%$ HPD: 0.3-7.5). Converting this estimate of $t$ to time in years suggests that the disjunct ranges of the Hooded Merganser split $\sim 57,000$ years ago (range: $10,000-357,000$ years). The parameter distribution for TMRCA peaked at 2.3 (95\% HPD: 1.4-3.7).

The observed mismatch distributions were unimodal (Fig. 4) and had similar modes for both western $(\tau=3.09$; 95\% CI: $1.5-5.6)$ and central-eastern samples ( $\tau=3.48$; 95\% CI: 1.7-6.6), which suggests connectivity (via gene flow) since divergence (see below). On the basis of estimates of $\tau$, we estimated that the entire North American population of Hooded Mergansers began expanding $\sim 60,000$ years ago (range: 25,000-157,000).

\section{Discussion}

Mark-recapture assessment of site fidelity.-Using a joint analysis of live-recapture and dead-recovery, we obtained a high estimate of breeding-site fidelity $(\sim 0.92)$ that did not differ between adult females known to have hatched on the study area versus those of unknown natal origins. Similarly high estimates $(>0.75)$ of the fidelity parameter from Burnham-type models have been observed in other waterfowl species, including the Common Goldeneye (Bucephala clangula, another cavity-nesting species; Barker and White 2001) and also for ground-nesting species of waterfowl, including three species of ducks in Europe (Common Pochard [Aythya ferina], Tufted Duck [A. fuligula], and Northern Shoveler [Anas clypeata]; Blums et al. 2002), Northern Pintails (A. acuta; Nicolai et al. 2005), and Mallards (A. platyrhynchos; Doherty et al. 2002). There is some uncertainty in our estimate of breeding-site fidelity (95\% CI: 0.64-0.98) and, thus, the level of fidelity could be lower (i.e., higher emigration).

Adult emigration by females may contribute to underestimates of survival for Hooded Mergansers when estimated by live-recapture information only. Our estimate of female annual survival probability $(S=0.72)$ is higher than that reported by Dugger et al. (1999), who used live-recapture information to estimate a survival probability $(\Phi)$ of 0.66 for female Hooded Mergansers. Because $\Phi$ is the product of survival and fidelity $(\Phi=S F)$, our estimates of survival and fidelity (0.72 and 0.92 , respectively) yield an estimate of 0.66 for $\Phi$, which is identical to that obtained by Dugger et al. (1999). It is important to acknowledge that our estimates of survival and fidelity are derived from a sample of nest boxes and, thus, may not be representative of birds nesting in natural cavities. Hooded Mergansers rely on tree cavities that are either excavated by other species or formed through tree growth or decay, but cavity availability across the landscape is unknown (but see Aitken et al. 2002).

Genetic assessment of site fidelity.-An expected outcome of high site fidelity by female waterfowl is population genetic differentiation, especially for mtDNA. However, we found four lines of genetic evidence that suggest female-mediated dispersal, by both juveniles and adults, may be more frequent than expected in the Hooded Merganser. First, we observed that some pairwise comparisons of sampling areas exhibit elevated levels of mtDNA 
differentiation, especially among breeding areas in the centraleastern range of the species (Table 3). However, these and continent-wide patterns of mtDNA distance do not fit a model of isolation-by-distance, especially between the disjunct western and central-eastern ranges. Second, we observed a lack of clustering of similar haplotypes by breeding area (Fig. 2), as is expected if dispersal is limited among areas. Third, nearly identical mismatch distributions of western and central-eastern ranges (Fig. 4) suggest a common population history and that the two ranges may not be demographically independent. An alternative explanation to the above three patterns is that Hooded Mergansers have experienced one or several periods of population splitting (vicariance) and expansion followed by zero gene flow, which has resulted in stochastic mtDNA lineage sorting and similar mismatch distributions across the continent. However, our IM analysis is in conflict with this alternative explanation, in that it suggests that gene flow is necessary to explain patterns of genetic variation between western and central-eastern ranges. Additionally, the IM analysis suggests that the disjunct ranges of the Hooded Merganser split 57,000 years ago (but perhaps as recently as 10,000 years ago), and this time-span is sufficient to structure mtDNA patterns in another cavity-nesting species of waterfowl that is also endemic to North America.

Comparative assessment.-Peters et al. (2005) examined mtDNA variation across the range of the Wood Duck, which also has a disjunct breeding and wintering range similar to that of the Hooded Merganser, is an obligate cavity-nester, and exhibits female breeding-site fidelity (Ransom et al. 2001). Peters et al. (2005) observed that the level of mtDNA genetic differentiation in Wood Ducks was nearly an order of magnitude greater $\left(\Phi_{\mathrm{ST}}=\right.$ 0.31 ) between disjunct western and eastern ranges than we report in Hooded Mergansers $\left(\Phi_{\mathrm{ST}}=0.05\right)$. In an IM analysis of their data, Peters et al. (2005) observed similar peak values to those of Hooded Mergansers for nearly all parameters, except $\theta_{\text {west }}$ and $m$, which were lower in Wood Ducks (Fig. 3). Peters et al. (2005) also found that the $95 \%$ CI for the migration parameter $(m)$ in Wood Ducks overlaps zero and suggested that the data were consistent with divergence followed by complete isolation of western and eastern groups. By contrast, our IM analysis rejected complete isolation following divergence (i.e., the $95 \%$ limits on the posterior distribution for $m$ did not overlap zero). In other words, the probability of no gene flow is very low, even though the disjunct ranges of the Hooded Merganser split within approximately the same time-frame as the Wood Duck (Fig. 3). Furthermore, the mtDNA haplotype networks for these two species are dissimilar, and no haplotypes are shared between western and eastern ranges of the Wood Duck as is observed in the Hooded Merganser.

Mismatch distributions also differ between the Wood Duck and Hooded Merganser and likely arise because of the different dispersal tendencies for these two species. In the Wood Duck, both population stability and growth were observed in western and eastern North America, respectively, which suggests limited dispersal and independent demographic histories since population divergence (fig. 4 in Peters et al. 2005). Furthermore, the timing of population expansion for eastern Wood Ducks $(\tau=3.4)$ and for the two ranges of Hooded Mergansers ( $\tau=3.1$ and 3.5; Fig. 4) are similar. Taken together, we conclude that the disjunct ranges of the Wood Duck and Hooded Merganser split within similar time-frames, but a higher rate of dispersal and emigration in the Hooded Merganser results in dissimilar genetic patterns when comparing the two species. Average dispersal distances of juvenile Hooded Mergansers are unknown, but direct recoveries of juveniles (Fig. 1) suggest that they can cross large distances after fledging. Greater movement probability among Hooded Mergansers is also evident from the geographic distribution of $>600$ recoveries of both Wood Duck and Hooded Merganser ducklings banded at hatch in Missouri. Of these recoveries, the proportion of northward, long-distance $(>500 \mathrm{~km})$ movements by Hooded Mergansers was nearly $5 \times$ that for Wood Ducks (27\% and $5 \%$, respectively). Additionally, most of the Hooded Merganser recoveries in this data set came from areas far north of Missouri (e.g., Great Lakes area) during the first autumn following hatch (Fig. 1E), but no direct recoveries of young Wood Ducks were obtained from these northern areas (P. Blums unpubl. data).

We lack the data to assess whether dispersal in the Hooded Merganser varies annually or geographically, but this also may explain the variation in levels of mtDNA differentiation across North America. Both Blums et al. (2002) and Nicolai et al. (2005) found a positive trend between habitat quality and fidelity rate in four other waterfowl species, and geographic variation in fidelity was observed among hatch-year Mallards by Doherty et al. (2002). Annual or geographic variation in dispersal, emigration, and cavity availability may also contribute to recent observations of population and range expansions of Hooded Mergansers across North America (Heusmann et al. 2000, Davis and Capobianco 2006, Pandolfino et al. 2006). Thus, both fidelity and dispersal have likely contributed to the stochastic pattern of mtDNA differentiation across the North American range of the Hooded Merganser. That is, through periods of random dispersal and colonization, the same mtDNA lineages could sort (via both extinction and fixation) to high frequencies in some subpopulations, but not in others. This stochastic effect could result in some subpopulations being genetically similar, whereas others are quite different regardless of the geographic distance between them. However, by combining inferences from mark-recapture, band-recovery, and genetic and comparative assessments, we are able to more conclusively show that female natal and breeding-site fidelity are lesser factors than juvenile dispersal and adult emigration by females for explaining the current mtDNA haplotype distribution of the Hooded Merganser.

\section{ACKNOWLEDGMENTS}

D. Derksen, S. Talbot, P. Flint, J. Peters, K. McCracken, C. Dau, J. Gust, and K. Sage were of tremendous assistance in this study. Numerous agencies and individuals contributed time, unpublished banding data and genetic material that made this study possible, including: P. Padding and K. Bollinger (U.S. Fish and Wildlife Service), B. Bower (Ottawa Duck Club), K. Timm, R. McNeil, and B. Braune (Environment Canada, Wildlife Toxicology Division, Specimen Bank), C. Davies (Ontario Ministry of Natural Resources), A. Weik (Maine Department of Inland Fisheries and Wildlife), E. Robinson (New Hampshire Fish and Game Department), R. Helm, M. Edmunds, T. Vidrine, M. Berg, and D. Hayden (Louisiana Department of Wildlife and Fisheries), L. Savoy (BioDiversity Research Institute), H. Heusmann (Massachusetts Division of Fisheries and Wildlife), J. Berdeen and J. DiMatteo (Minnesota Department of Natural Resources), 
T. Sutter (New York Department of Environmental Conservation), S. Birks (Burke Museum of Natural History and Culture), B. Dugger and H. Meyer (Oregon State University), and R. Strand. D. Berthiaume assisted with initial genotype screening and D. Ruthrauff helped with the maps. We thank L. Bollmann, R. Kelly, and P. Lemons for assistance with data collection at Mingo Swamp, Missouri. This research was supported by the North American Sea Duck Joint Venture, the U.S. Geological Survey, Alaska Science Center, the Department of Biology and Wildlife at the University of Alaska, Fairbanks, and the Missouri Department of Conservation and Gaylord Memorial Laboratory, University of Missouri. K. McCracken, P. Flint, L. Fredrickson, and two anonymous reviewers offered comments on an earlier version of the manuscript. Any use of trade, product, or firm names in this publication is for descriptive purposes only and does not imply endorsement by the U.S. Government.

\section{Literature Cited}

Aitken, K. E. H., K. L. Wiebe, and K. Martin. 2002. Nest-site reuse patterns for a cavity-nesting bird community in interior British Columbia. Auk 119:391-402.

Anderson, M. G., J. M. Rhymer, And F. C. Rowher. 1992. Philopatry, dispersal, and the genetic structure of waterfowl populations. Pages 365-395 in Ecology and Management of Breeding Waterfowl (B. D. J. Batt, A. D. Afton, M. G. Anderson, C. D. Ankney, D. H. Johnson, J. A. Kadlec, and G. L. Krapu, Eds.). University of Minnesota Press, Minneapolis.

Austin, J. J., R. W. G. White, And J. R. Ovenden. 1994. Populationgenetic structure of a philopatric, colonially nesting seabird, the Short-tailed Shearwater (Puffinus tenuirostris). Auk 111:70-79.

Avise, J. C. 2004. Molecular Markers, Natural History, and Evolution, 2nd ed. Sinauer Associates, Sunderland, Massachusetts.

Avise, J. C., R. T. Alisauskas, W. S. Nelson, and C. D. Ankney. 1992. Matriarchal population genetic structure in an avian species with female natal philopatry. Evolution 46:1084-1096.

Bandelt, H.-J., P. Forster, And A. RöHL. 1999. Median-joining networks for inferring intraspecific phylogenies. Molecular Biology and Evolution 16:37-48.

BARKER, R. J., AND G. C. White. 2001. Joint analysis of live and dead encounters of marked animals. Pages 361-367 in Wildlife, Land, and People: Priorities for the 21st Century (R. Field, R. J. Warren, H. Okarma, and P. R. Sievert, Eds.). Proceedings of the Second International Wildlife Management Congress. Wildlife Society, Bethesda, Maryland.

Blums, P., J. B. Davis, S. E. Stephens, A. Mednis, and D. M. RichARDSON. 1999. Evaluation of a plasticine-filled leg band for day-old ducklings. Journal of Wildlife Management 63:656-663.

Blums, P., A. Mednis, AND J. D. Nichols. 1994. Retention of web tags and plasticine-filled leg bands applied to day-old ducklings. Journal of Wildlife Management 58:76-81.

Blums, P., J. D. Nichols, J. E. Hines, ANd A. Mednis. 2002. Sources of variation in survival and breeding site fidelity in three species of European ducks. Journal of Animal Ecology 71:438-450.

Buchholz, W. G., J. M. Pearce, B. J. Pierson, and K. T. Scribner. 1998. Dinucleotide repeat polymorphisms in waterfowl (family Anatidae): Characterization of a sex-linked (Z-specific) and 14 autosomal loci. Journal of Animal Genetics 29:323-325.
Burg, T. M., AND J. P. Croxall. 2004. Global population structure and taxonomy of the Wandering Albatross species complex. Molecular Ecology 13:2345-2355.

BURNHAM, K. P. 1993. A theory for combined analysis of ring recovery and recapture data. Pages 199-213 in Marked Individuals in the Study of Bird Population (J.-D. Lebreton and P. M. North, Eds.). Birkhauser Verlag, Basel, Switzerland.

Burnham, K. P., And D. R. Anderson. 2002. Model Selection and Multimodel Inference: A Practical Information-theoretic Approach, 2nd ed. Springer-Verlag, New York.

Davis, S., And P. Capobianco. 2006. The Hooded Merganser: A preliminary look at growth in numbers in the United States as demonstrated in the Christmas Bird Count Database. American Birds 60:27-33.

Doherty, P. F., JR., J. D. Nichols, J. Tautin, J. F. Voelzer, G. W. Smith, D. S. Benning, V. R. Bentley, J. K. Bidwell, K. S. Bollinger, A. R. BrazdA, AND Others. 2002. Sources of variation in breeding-ground fidelity of Mallards (Anas platyrhynchos). Behavioral Ecology 13:543-550.

Donne-Goussé, C., V. LAudet, And C. HäNni. 2002. A molecular phylogeny of Anseriformes based on mitochondrial DNA analysis. Molecular Phylogenetics and Evolution 23:339-356.

Dugger, B. D., K. M. Dugger, And L. H. Fredrickson. 1994. Hooded Merganser (Lophodytes cucullatus). In The Birds of North America, no. 98 (A. Poole and F. Gill, Eds.). Academy of Natural Sciences, Philadelphia, and American Ornithologists' Union, Washington, D.C.

Dugger, K. M., B. D. Dugger, And L. H. Fredrickson. 1999. Annual survival rates of female Hooded Mergansers and Wood Ducks in southeastern Missouri. Wilson Bulletin 111:1-6.

Emerson, B. C., E. Paradis, And C. ThéBAud. 2001. Revealing the demographic histories of species using DNA sequences. Trends in Ecology and Evolution 16:707-716.

Excoffier, L., G. LAVAL, AND S. SCHNeIder. 2005. ARLEQUIN version 3.0: An integrated software package for population genetics data analysis. Evolutionary Bioinformatics Online 1:47-50.

Gautschi, B., And B. Koller. 2005. Polymorphic microsatellite markers for the Goosander (Mergus merganser). Molecular Ecology Notes 5:133-134.

GOUDET, J. 1995. FSTAT (version 1.2): A computer program to calculate $F$-statistics. Journal of Heredity 86:485-486.

Guo, S. W., And E. A. Thompson. 1992. Performing the exact test of Hardy-Weinberg proportion for multiple alleles. Biometrics 48:361-372.

Hefti-Gautschi, B., M. Pfunder, L. Jenni, V. Keller, and H. Ellegren. 2008. Identification of conservation units in the European Mergus merganser based on nuclear and mitochondrial DNA markers. Conservation Genetics 9: in press.

Heusmann, H. W., T. J. Early, and B. J. Nikula. 2000. Evidence of an increasing Hooded Merganser population in Massachusetts. Wilson Bulletin 112:413-415.

Hey, J., AND R. Nielsen. 2004. Multilocus methods for estimating population sizes, migration rates and divergence time, with applications to the divergence of Drosophila pseudoobscura and D. persimilis. Genetics 167:747-760.

Kalinowski, S. T. 2004. Counting alleles with rarefaction: Private alleles and hierarchical sampling designs. Conservation Genetics 5:539-543. 
Kimura, M., S. M. Clegg, I. J. Lovette, K. R. Holder, D. J. Girman, B. Milá, P. Wade, And T. B. Smith. 2002. Phylogeographical approaches to assessing demographic connectivity between breeding and overwintering regions in a NearcticNeotropical warbler (Wilsonia pusilla). Molecular Ecology 11: 1605-1616.

LiNdBerg, M. S., J. S. Sedinger, D. V. DERKSEN, AND R. F. RoCKWELL. 1998. Natal and breeding philopatry in a Black Brant, Branta bernicla nigricans, metapopulation. Ecology 79:1893-1904.

MaAK, S., K. Wimmers, S. Weigend, and K. Neumann. 2003. Isolation and characterization of 18 microsatellites in the Peking Duck (Anas platyrhynchos) and their application in other waterfowl species. Molecular Ecology Notes 3:224-227.

Mayr, E. 1963. Animal Species and Evolution. Belknap Press of Harvard University Press, Cambridge, Massachusetts.

NeI, M. 1987. Molecular Evolutionary Genetics. Columbia University Press, New York.

Nicolai, C. A., P. L. Flint, And M. L. Wege. 2005. Annual survival and site fidelity of Northern Pintails banded on the Yukon-Kuskokwim Delta, Alaska. Journal of Wildlife Management 69:1202-1210.

Nielsen, R., And J. Wakeley. 2001. Distinguishing migration from isolation: A Markov chain Monte Carlo approach. Genetics 158:885-896.

North American Waterfowl Management Plan, Plan CoMmitTeE. 2004. Implementation Framework: Strengthening the Biological Foundation. Canadian Wildlife Service, U.S. Fish and Wildlife Service, and Secretaria de Medio Ambiente y Recursos Naturales.

Omland, K. E., J. M. Baker, And J. L. Peters. 2006. Genetic signatures of intermediate divergence: Population history of Old and New World Holarctic ravens (Corvus corax). Molecular Ecology 15:795-808.

Pandolfino, E. R., J. Kwolek, And K. Kreitinger. 2006. Expansion of the breeding range of the Hooded Merganser within California. Western Birds 37:228-236.

Pearce, J. M. 2006. Minding the gap: Frequency of indels in mtDNA control region sequence data and influence on population genetic analyses. Molecular Ecology 15:333-341.

Pearce, J. M. 2007. Philopatry: A return to origins. Auk 124: 1085-1087.

Pearce, J. M., and S. L. Talbot. 2006. Demography, genetics, and the value of mixed messages. Condor 108:474-479.

Pearce, J. M., S. L. Talbot, B. J. Pierson, M. R. Petersen, K. T. SCribner, D. L. Dickson, ANd A. MosBeCH. 2004. Lack of spatial genetic structure among nesting and wintering King Eiders. Condor 106:229-240.

Peters, J. L., W. Gretes, And K. E. Omland. 2005. Late Pleistocene divergence between eastern and western populations of Wood
Ducks (Aix sponsa) inferred by the 'isolation with migration' coalescent method. Molecular Ecology 14:3407-3418.

Peters, J. L., And K. E. Omland. 2007. Population structure and mitochondrial polyphyly in North American Gadwalls (Anas strepera). Auk 124:444-462.

Pollock, K. H. 2002. The use of auxiliary variables in capturerecapture modelling: An overview. Journal of Applied Statistics 29:85-102.

Posada, D., AND K. A. CRAndAll. 1998. MODELTEST: Testing the model of DNA substitution. Bioinformatics 14:817-818.

Ransom, D., JR., R. L. Honeycutt, and R. D. Slack. 2001. Population genetics of southeastern Wood Ducks. Journal of Wildlife Management 65:745-754.

RAYMOND, M., AND F. Rousset. 1995. GENEPOP (version 1.2): Population genetics software for exact tests and ecumenicism. Journal of Heredity 86:248-249.

Roeder, A. D., R. K. Marshall, A. J. Mitchelson, T. Visagathilagar, P. A. Ritchie, D. R. Love, T. J. Pakai, H. C. McPartlan, N. D. Murray, N. A. Robinson, and others. 2001. Gene flow on the ice: Genetic differentiation among Adélie Penguin colonies around Antarctica. Molecular Ecology 10: 1645-1656.

Rogers, A. R., And H. Harpending. 1992. Population growth makes waves in the distribution of pairwise genetic differences. Molecular Biology and Evolution 9:552-569.

SÆther, B.-E., AND Ø. BAKKe. 2000. Avian life history variation and contribution of demographic traits to the population growth rate. Ecology 81:642-653.

Sorenson, M. D., AND T. W. Quinn. 1998. Numts: A challenge for avian systematics and population biology. Auk 115: 214-221.

TAMURA, K., AND M. NeI. 1993. Estimation of the number of nucleotide substitutions in the control region of mitochondrial DNA in humans and chimpanzees. Molecular Biology and Evolution 10:512-526.

Van Bekkum, M., P. M. Sagar, J.-C. Stahl, and G. K. ChamBERS. 2006. Natal philopatry does not lead to population genetic differentiation in Buller's Albatross (Thalassarche bulleri bulleri). Molecular Ecology 15:73-79.

Villesen, P. 2007. FaBox: An online toolbox for FASTA sequences. Molecular Ecology Notes 7:965-968.

White, G. C., and K. P. Burnham. 1999. Program MARK: Survival estimation from populations of marked animals. Bird Study 46 (Supplement):S120-S138.

Whitlock, M. C., AND D. E. MCCAUley. 1999. Indirect measures of gene flow and migration: $F_{\mathrm{ST}} \neq 1 /(4 \mathrm{Nm}+1)$. Heredity $82: 117-125$.

Williams, B. K., J. D. Nichols, And M. J. Conroy. 2002. Analysis and Management of Animal Populations. Academic Press, San Diego, California.

Associate Editor: J. Klicka 